\title{
GABA and Muscimol as Reversible Inactivation Tools in Learning and Memory
}

\author{
M. Majchrzak and G. Di Scala \\ Laboratoire de Neurociences Comportementales et Cognitives \\ LN2C UMR7521 ULP/CNRS, 12 rue Goethe 67000 Strasbourg, France
}

\begin{abstract}
Reversible inactivation of brain areas is a useful method for inferring brain-behavior relationships. Infusion of GABA or of the GABA receptor agonist muscimol is considered one interesting reversible inactivation method because it may not affect fibers of passage and may therefore be compared to axon-sparing types of lesions. This article reviews the data obtained with this method in learning and memory experiments. A critical analysis of data, collected in collaboration with Simon Brailowsky, with chronic GABA infusion is presented, together with an illustration of data obtained with muscimol-induced inactivation.
\end{abstract}

\section{KEYWORDS}

amygdala, GABA, frontal cortex, learning, memory, muscimol, nucleus basalis magnocellularis

\section{INTRODUCTION}

Considerable insight into the molecular mechanisms that are involved in learning and memory has been gained in recent years (for example, Lynch, 1998). Nevertheless, as stated by Bures and Buresova (1990):

In spite of its importance, research specifying plastic phenomena at the microscale cannot lead to understanding of the mechanisms of learning and memory without a commensurate progress of system studies showing where and when the cellular changes take place.

In this regard, neuropsychological analysis of brain-injured patients has profoundly influenced the present conception of memory systems (for example, Tulving, 1991). In animal studies, new paradigms have been introduced to explore the multiplicity of the processes underlying these memory systems, and new techniques (for example, expression of immediate early genes) have been adapted to identify the brain networks supporting these processes. Lesion techniques in animals have also improved in neuroanatomical selectivity, using excitotoxic compounds (for example, ibotenate, AMPA [ $\alpha$-amino-3-hydroxy5-methyl-4-isoxazole propionic acid], quisqualate) that destroy cell bodies without affecting the fibers of passage. For instance, in the ongoing debate on the role of the hippocampus in learning and memory, it has been found that part of the deficits (in particular, some nonspatial learning deficits), induced by mechanical or electrolytic lesions, may to be due to damage to neighboring structures rather than to the hippocampus itself (for example, Jarrard, 1993). Despite this progress, the various shortcomings of lesions studies for inferring brain-behavior relationships must be recognized. One drawback is that inference about a relation between brain damage and a behavioral deficit implicitly supposes that the undamaged components of the system continue to function normally (see Jaffard \& Meunier, 1993; Farah, 1994), which is unlikely 
to be the case. Somewhat related to the preceding, lesion effects are usually tested after a necessary recovery period from surgery; during that time, various restorative and/or adaptive processes occur that may obscure the primary effect of the lesion. For example, several studies have reported partial or complete recovery of cholinergic markers within the cortex after unilateral excitotoxic lesions of the nucleus basalis magno-cellularis (NBM), provided that a sufficient recovery period $(3 \mathrm{mo})$ was respected (for example, Wenk \& Olton, 1984; Gardiner et al., 1987; Casamenti et al., 1988). Returning to Bures and Buresova's statement, brain lesions certainly contribute to our knowledge of where in the brain plastic changes may occur during learning. Because they are irreversible, however, brain lesions rarely indicate when plastic changes occur. In this regard, reversible inactivation of brain areas has proved to be an efficient tool to complement lesion studies in various fields of research, including the study of learning and memory. This article aims to briefly present data obtained with GABA or GABA agonists as reversible inactivation tools, with a special emphasis on data obtained in collaboration with Simon Brailowsky.

\section{GABA AND REVERSIBLE INACTIVATION}

GABA-induced inactivation has a rapid onset and a short duration; its principal use has been in anesthetized animals. For example, acute injection of GABA into the anterodorsal tegmentum of anesthetized rats $(0.25$ to $1.0 \mathrm{mg} / \mu \mathrm{L}$ saline, injection volume of 0.1 or $0.2 \mu \mathrm{L}$ ) was found to block the locomotion that is elicited by hypo-thalamic stimulation within $5 \mathrm{~min}$ of the injection, with recovery occurring within 10 to 20 min (Sinnamon \& Benaur, 1997). A similar onset and recovery time of the reaction time to a stimulustriggered movement was recently reported by Martin and Ghez (1999) after GABA injection into the magnocellular red nucleus of cats.
Spatial and temporal characteristics of the inactivation induced by GABA, administered into cortical sites, has been recently reviewed by Hupé et al. (1999). Repeated injections of small doses of GABA have been reported (a) to induce a more homogeneous inactivation than a single injection of larger amounts does, and (b) to increase the duration of inactivation (Hupé et al., 1999).

Although the short duration of GABAinduced inactivation is not compatible with learning and memory tests, this inconsistency can be compensated for by infusing the GABA constantly over a period of time, using subcutaneous osmotic minipumps (Alzet ${ }^{\circledR}$ ). Through the appropriate choice of the minipump model, duration and rate of infusion (for example, $1 \mu \mathrm{L} / \mathrm{h}$ for $7 \mathrm{~d}$ using the 2001 model) can be chosen to fit the experimental design. In a series of studies, Brailowsky and collaborators (1989) showed that chronic GABA infusion is an efficient method to inactivate brain regions involved in memory processes. Delayed responses depend on the prefrontal cortex (for example, Kolb, 1984). Infusion of GABA $(50 \mu \mathrm{g} / \mu \mathrm{l})$ over 7 days after acquisition of the task was found to impair the delayed response in monkeys (Brailowsky et al., 1989) and rats (Di Scala et al., 1990; Meneses et al., 1993). This deficit was found to be relatively stable over the treatment period (for example, Meneses et al., 1993), and rapid recovery of performance occurred upon cessation of the treatment. In this cortical area, histological examination of the sites of infusion did not reveal clear signs of lesions (at least, not larger than those after vehicle infusion, Di Scala et al., 1990; Meneses et al., 1993).

The NBM, the main source of cortical acetylcholine afferents, has been implicated in attentional and working memory processes (Dunnett et al., 1991; Muir et al., 1993; McDonald \& Overmier, 1998). As cholinergic NBM neurons receive a massive GABAergic innervation (for example, Wood \& Richard, 1982; Zaborsky et al., 1986; Ingham et al., 1988), 
acting on NBM GABA receptors constitutes a means to modify the activity of these neurons. Infusion of small doses of GABA $(10 \mu \mathrm{g} / \mu \mathrm{L} / \mathrm{h})$ induces a delay-dependent deficit in a previously learned win-shift task in a radial maze (Majchrzak et al., 1990). This effect is consistent with the reported deficit after excitotoxic (ibotenate) lesion of the NBM (for example, Bartus et al., 1985). Infusions of higher doses (50 or $100 \mu \mathrm{g} / \mu \mathrm{L} / \mathrm{h}$ ) of GABA induces a delayindependent deficit in the win-shift task (Majchrzak et al., 1990), together with profound sensorimotor impairments (Will et al., 1988; Majchrzak et al., 1990; 1992a). With both doses, the deficits appeared to be reversible because performance recovered shortly after interruption of the infusion.

In a series of experiments, possible longlasting (or irreversible) effects of GABA infusion into the NBM were evaluated. To characterize the spatial extent of the inactivation induced by GABA infusion, Majchrzak et al., (1992b) measured local cerebral metabolic rates for glucose (CMRglc) after 24-h infusions of GABA. The results showed that despite its efficacy on the memory task, infusion of a small dose $(10 \mu \mathrm{g} / \mu \mathrm{L} / \mathrm{h})$ did not modify (in comparison with saline-treated animals) CMRglc within the $\mathrm{NBM}$, in neighboring structures, or in NBM cortical projection areas (frontal and parietal cortex). In contrast, infusion of high doses of GABA $(100 \mu \mathrm{g} / \mu \mathrm{L} / \mathrm{h})$ induced a strong reduction of CMRglc within the NBM, as well as in neighboring structures (for example, globus pallidus) and NBM projection areas (frontal and parietal cortex, amygdala, reticular thalamic nucleus). Such distant hypometabolic effects of GABA infusion may reflect an NBM reduction of synaptic activity, but also may be due to degenerative processes. Indeed, Browne et al. (1998) have shown that intra-NBM injections of excitotoxic compounds (NMDA and AMPA) rapidly induce a reduction of glucose utilization in interconnected cortical areas.

Further evidence of irreversible lesion with a high dose (50 or $100 \mu \mathrm{g} / \mu \mathrm{L} / \mathrm{h}$ ) of GABA, but not with a smaller dose $(10 \mu \mathrm{g} / \mu \mathrm{L} / \mathrm{h})$, was obtained using a variety of techniques. Infusion of a high dose of GABA $(100 \mu \mathrm{g} / \mu \mathrm{L} / \mathrm{h})$ into the NBM induced neuronal damage within this nucleus, which could be observed on Cresyl violet-stained sections (see Fig. 1).

The loss of magnocellular cholinergic neurons was confirmed by reduced acetylcholinesterase (AChE) and choline acetyltransferase (ChAT) activities in the frontal and parietal cortices (see Fig. 2; Will et al., 1988; Majchrzak et al., 1990; 1992; Majchrzak, 1992). In another study (Ballough et al., 1992), two wellestablished bioindicators of neurotoxicity, azure B-RNA and Feulgen-DNA expression, were used to examine the putative cytopathic effects of GABA infusion into the basal forebrain. This method revealed a reduced neuronal RNA metabolism shortly ( $24 \mathrm{~h}$ ) after infusion, even when using the small dose. In the latter case, however, this effect disappeared within an 8-d postinfusion delay.

Taken together, the data indicate that GABA injection is an efficient method to inactivate a brain area; the data also indicate that the effects of chronic GABA infusion may not be reversible, mainly when high doses are used. A series of biological parameters (see above), as well as the mere existence of the GABA-withdrawal syndrome (see Brailowsky et al., 1987; Fukuda et al., 1987; Brailowsky et al., 1988; 1989) are indicative of plastic and/or degenerative effects.

\section{MUSCIMOL-INDUCED REVERSIBLE INACTIVATION}

Muscimol rapidly induces a hyperpolarization lasting several hours, with the overall duration depending on the dose (see Martin \& Ghez, 1993; 1999). In a series of articles, Martin and colleagues (for example, Martin, 1991; Martin \& Ghez, 1999) provided a thorough analysis of muscimol-induced inactivation, together with 

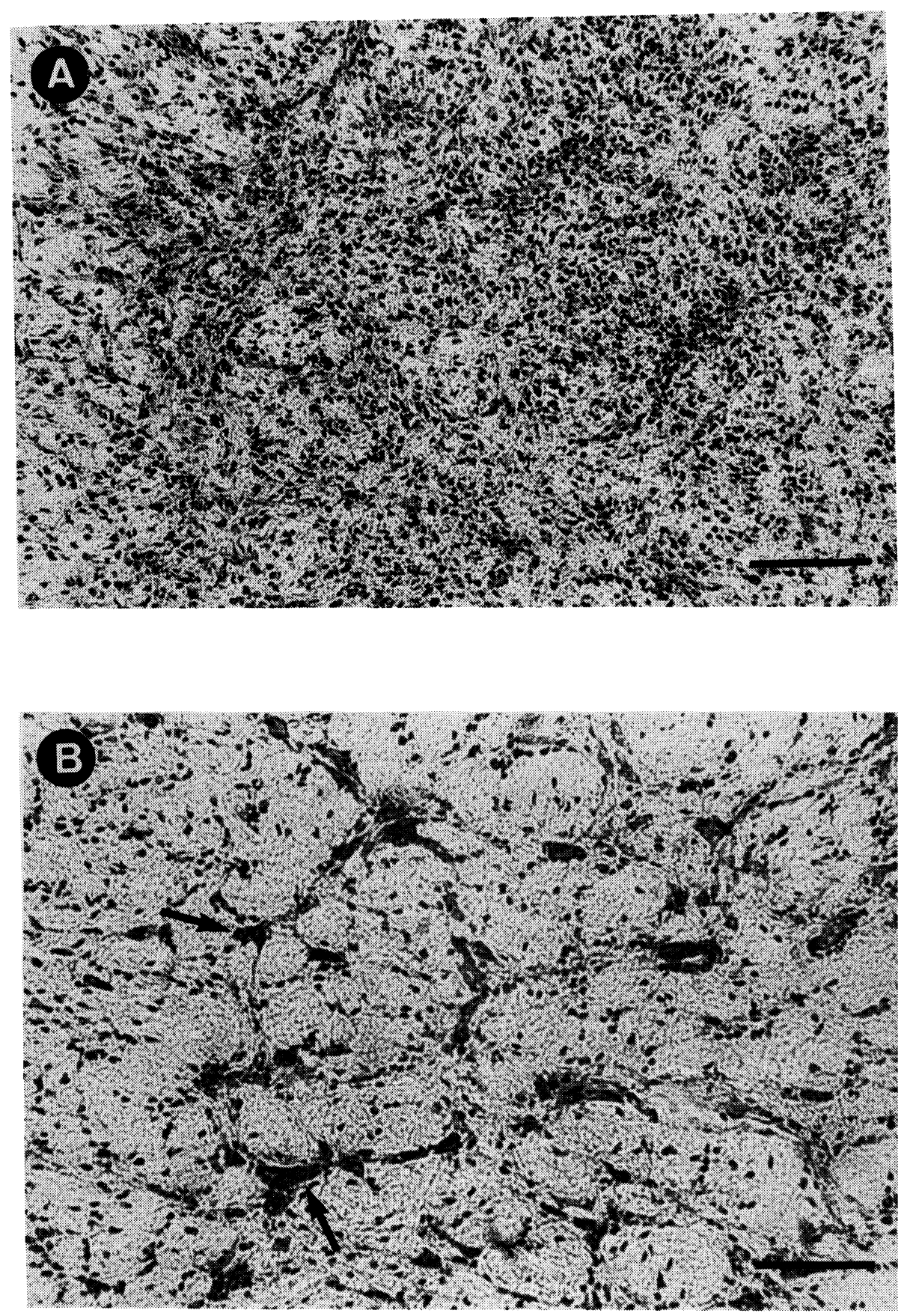

Fig. 1: Photomicrographs of coronal sections of (A) the NBM of a rat after $24-\mathrm{h} \mathrm{GABA}(100 \mu \mathrm{g} / \mu \mathrm{L} / \mathrm{h})$ infusion, and (B) the contralateral noninfused NBM. The brain was processed for Cresyl violet staining 8 days after the infusion. The arrows in B indicate the magnocellular neurons that are lacking in A; note the strong gliotic reaction in A. Scale bars: $100 \mu \mathrm{m}$. 
comparisons with other reversible inactivating agents (GABA, lidocaine). These experiments showed that autoradiographic measurement of $\left[{ }^{14} \mathrm{C}\right]$ glucose uptake, following injection of muscimol $(1 \mu \mathrm{g} / \mu \mathrm{L})$ into the cerebral cortex of rats, revealed a small area $(1 \mathrm{~mm})$ of strong hypometabolism, surrounded by an area of milder hypometabolism. This hypometabolic area exceeded the spread of the drug that was evaluated with $\left[{ }^{3} \mathrm{H}\right]$ muscimol injection, indicating that the area of hypometabolism may be due to reduced synaptic activity in interconnected neurons. In this regard, muscimol and lidocaine induced the same type of inactivation.

Muscimol-induced inactivation has been used in diverse species in a variety of behavioral experiments (for example, Di Scala et al., 1983; Martin \& Ghez, 1993; Gallese et al., 1994; Mason et al., 1998), including learning and memory experiments (for example, Matsumara et al., 1991; Hardiman et al., 1996; Krupa et al., 1996; Ramnani \& Yeo, 1996; Milak et al., 1997; Baunez \& Robbins, 1999). The following section does not attempt to provide an exhaustive review of these experiments, but rather illustrates some questions that can be addressed with this type of

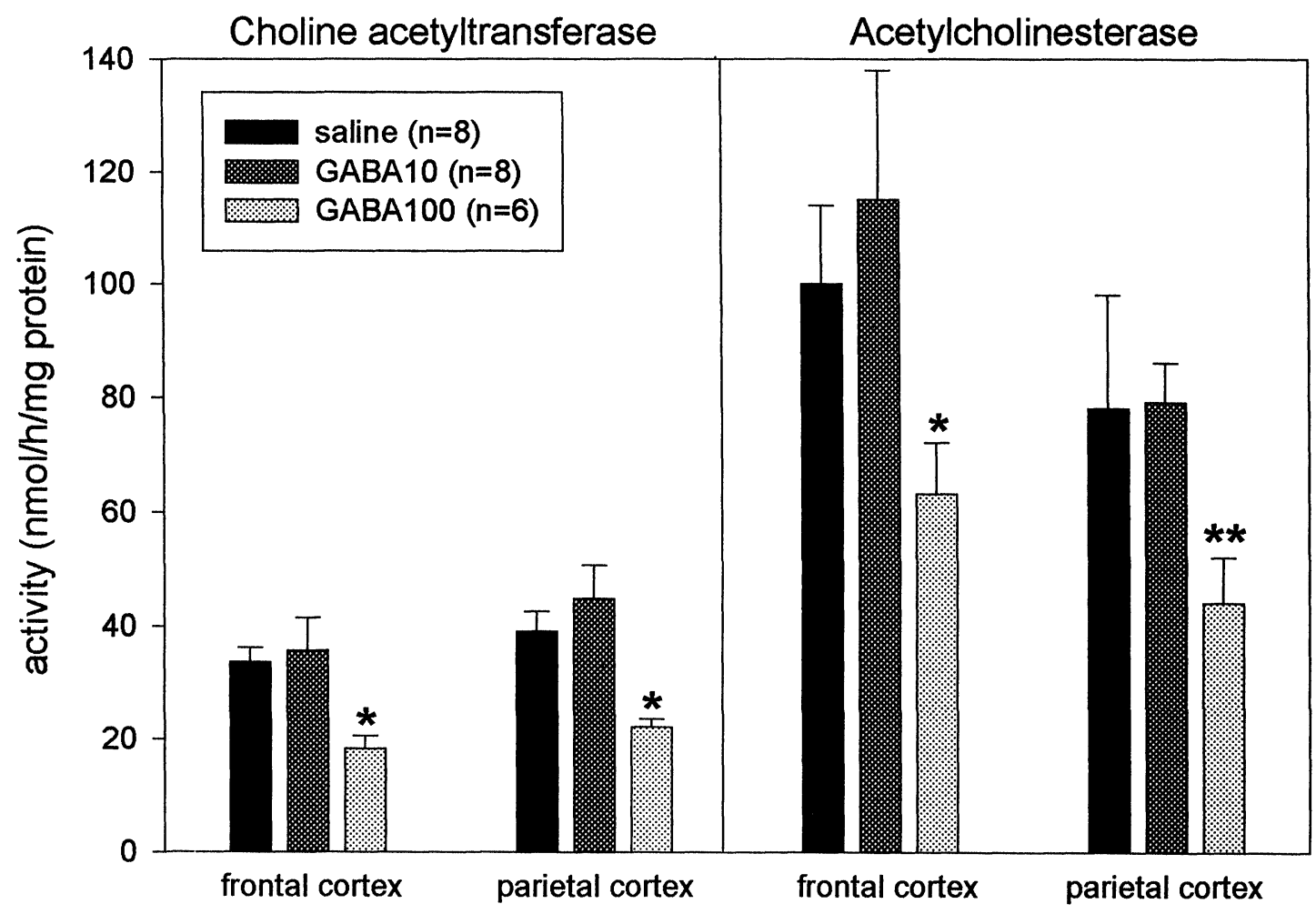

Fig. 2: The effect of GABA infusion into the NBM on cholinergic markers in frontal and parietal cortices. Saline or GABA (10 or $100 \mu \mathrm{g} / \mu \mathrm{L} / \mathrm{h}$ ) were infused over $24 \mathrm{~h}$. Fourteen days later, the rats were sacrificed, and the frontal and parietal cortices were rapidly dissected. Choline acetyltransferase and acetylcholinesterase activities were assayed using enzymatic methods (Fonnum, 1975; Ellman et al., 1961). The highest concentration of GABA induced a significant reduction of both cholinergic markers as compared with saline ( ${ }^{*} \mathrm{p}<0.05 ;{ }^{* *} \mathrm{p}<0.01$; Newman-Keuls post-hoc comparisons). 
reversible inactivation.

As mentioned earlier, GABA receptors, located on NBM cholinergic neurons, may constitute a target to modify the activity of these neurons. Muscimol injection into the NBM was found to impair the performance of rats in attentional tasks, such as two- and five-choice reaction time (Muir et al., 1992; Pang et al., 1993) or conditioned discrimination (Dudchenko \& Sarter, 1991). The effects were similar to those obtained with excitotoxic lesions of the NBM, including AMPA lesion, which is thought to have a preferential effect on cholinergic neurons (Muir et al., 1995; Everitt et al., 1987; Robbins et al., 1989). Working memory deficits in a double $\mathrm{Y}$-maze were reported after intra-NBM injections of small doses of muscimol $(0.1 \mu \mathrm{g}$; Beninger et al., 1992; DeSousa et al., 1994), whereas both working and reference memory deficits were obtained after injecting higher doses $(1 \mu \mathrm{g}$ Beninger et al., 1992).

Similar effects, confined to working memory, were obtained after quisqualate lesion (Biggan et al., 1991; Beninger et al., 1994), which induces restricted NBM lesions (Dunnett et al., 1987) when compared with the working and reference memory deficits that are obtained after ibotenate lesions (see Dunnett et al., 1991). The data support the idea that muscimol injection induces a reversible inactivation, the effects of which are similar to those of excitotoxic lesions. Moreover, in the NBM, such effects may be related to an action on cholinergic neurons, as excitotoxic compounds having some selectivity for these neurons have similar effects. Nonetheless, the deficits induced by intra-NBM injection of the selective cholinergic neurons toxin, ${ }^{192} \mathrm{IgG}$ saporin, are smaller than those induced by muscimol in a variety of tests (Torres et al., 1994; Wenk et al., 1994; Baxter et al., 1995), suggesting that the behavioral deficits induced by muscimol may depend also on its effects on noncholinergic NBM neurons.

The amygdala is involved at various stages of learning and memory, and reversible inactivation studies. Using tetrodotoxine (TTX), lidocaine (or novocaine), and muscimol have largely contributed to the identification of these processes (for example, Gallo et al., 1992; Willner et al., 1993; Jerusalinsky et al., 1994; Muller et al., 1997; Ambrogi-Lorenzini et al., 1999). In this regard, conditioned food-aversion procedures have been considered particularly appropriate to realize a "chronometric analysis" of the various processes that are involved in learning and memory, with the aid of reversible inactivation (see Bures, 1990; Bures \& Buresova, 1990). In these procedures, intake of a food by the rat (a drinking solution, which may be identified by its taste or its odor) is followed by intoxication, induced by injection of lithium chloride, resulting in avoidance of the food upon subsequent encounter. Using TTX to inactivate a variety of brain structures at specific phases of a conditioned taste aversion, Bures and collaborators (Bures, 1990; Gallo et al., 1992) have exquisitely documented the involvement of the connections between the parabrachial nucleus, the amygdala, and the gustatory cortex in this learning. In a recent series of experiments, we used muscimol to study the neuroanatomical substrate that is involved in a particular instance of conditioned food aversion, which is conditioned odor aversion (COA). Conditioned odor aversion is the avoidance of a tasteless, odorized solution, the ingestion of which has preceded toxicosis; COA differs from the classic conditioned taste aversion (CTA) in that it does not tolerate long interstimulus intervals (ISI) between the solution intake and the induction of toxicosis (Hankins et al., 1973). Nonetheless, evidence exists of COA that is acquired despite long ISIs when the odor is presented together with a taste during acquisition; this procedure is called Taste-Potentiated Odor Aversion (TPOA). TPOA depends on the baso-lateral nucleus of the amygdala (BLA), as electrolytic or excitotoxic lesions of this nucleus were found to disrupt it (Bermudez-Rattoni et al, 1986; Hatfield et al., 1992; Ferry et al., 1995). Muscimol-induced inactivation of the BLA during the acquisition phase, but not 
during the retrieval phase, of the procedure was found to be effective, suggesting that this nucleus is involved in the former process. Furthermore, to be effective, muscimol could be injected either before or after presentation of the odor-taste stimulus, suggesting that neuronal activity in the BLA is necessary after the sensory processing of the composite stimulus, that is for a memory process (Ferry et al., 1995). In this regard, muscimol injection differs from other reversible inactivation compounds in that injection of novocaine into the amygdala impairs TPOA if it is administered before, but not after, presentation of the odor-taste stimulus (Bermudez-Rattoni et al., 1983). Conversely, it is noticeable that whether injected before or after presentation of the odor-taste stimulus, muscimol selectively affects COA without affecting CTA (tested separately), which develop in parallel. This result is consistent with those of Gallo et al. (1992) showing that inactivating the amygdala by TTX before taste presentation does not impair CTA, whereas inactivating the amygdala after taste presentation only attenuates CTA. The data, if suggestive of subtle differences between different methods of reversible inactivation, do not support a clear-cut distinction between these methods.

\section{DISCUSSION}

The data briefly reviewed above clearly indicate that GABA or GABA-receptor agonists constitute valuable reversible inactivation tools for studying learning and memory. Our critical analysis of the data obtained with chronic infusions of GABA, one of Simon Brailowsky's favorite tools, suggests that depending on the dose used and the targeted area, some effects may not be reversible. To our knowledge, little attention has been given to possible long-lasting effects of other compounds that are used for reversible inactivation (see however, Hernandez $\&$ Schallert, 1990) and hence, comparison of the advantages and drawbacks of the various methods is not possible. The issue of reversibility is particularly important when animals are tested anew after the reversible inactivation, as it is then considered that the system is fully functional again. In this regard, little empirical evidence demonstrating complete reversibility of any pharmacological treatment is available.

Another concern with reversible inactivation in learning tasks is state-dependent retrieval (SDR). State-dependent retrieval means that information learned in a given state may not be (or may be poorly) retrieved when the subject is in a different state. Evidence for SDR has been obtained with systemic pharmacological treatments given at various stages (acquisition, extinction) of learning tasks (for example, Colpaert, 1990; Bouton et al, 1990; Oberling et al., 1996) and has been taken into account when discussing reversible inactivation data (for example, Muller et al., 1997). It is unknown to what extent drug injections into brain areas can produce SDR, and studies addressing this problem would certainly be welcome.

As a final comment, reversible inactivation techniques significantly contribute to the knowledge of "where and when" (Bures \& Buresova, 1990) neuronal events for learning and memory take place in the brain. As first stated in this article, knowledge about the nature of such neuronal events has considerably progressed in recent years. Using research strategies similar to reversible inactivation, antisense oligonucleotide techniques offer the opportunity to interfere with neuronal events in precise locations in the brain and at chosen phases of a task (for example, Lamprecht et al., 1997; Guzowski \& McGaugh, 1997; Ma et al., 1998). There is little doubt that such techniques will shortly complement the pharmacological analysis of brain systems of learning and memory.

\section{REFERENCES}

Ambrogi-Lorenzini CG, Baldi E, Bucherelli C, Saccheti B, Tassoni G. Neural topography and chronology of memory consolidation: a review 
of functional inactivation findings. Neurobiol Learning and Memory 1999; 71: 1-18.

Ballough G, Majchrzak M, Strauss J, Kan R, Anthony A, Will B. Cytophotometric analysis of magnocellular azure B-RNA and Feulgen-DNA following chronic GABA infusion into the nucleus basalis of rats. Life Sci 1992; 50:1299-1310.

Bartus RT, Flicker C, Dean RL, Pontecorvo M, Figueiredo JC, Fisher SK. Selective memory loss following nucleus basalis lesions: long term behavioral recovery despite persistent cholinergic deficiencies. Pharmacol Biochem Behav 1985; 23: 125-135.

Baunez C, Robbins TW. Effects of transient inactivation of the subthalamic nucleus by local muscimol and APV infusions on performance in the five-choice serial reaction time task in rats. Psychopharmacology (Berl) 1999; 141: 57-65.

Baxter MG, Bucci DJ, Gorman LK, Wiley RG, Gallagher M. Selective immunotoxic lesions of basal forebrain cholinergic cells: effects on learning and memory in rats. Behav Neurosci 1995; 109: 714-722.

Beninger RJ, Ingles JL, Mackenzie PJ, Jhamandas $\mathrm{K}$, Boegman RJ. Muscimol injections into the nucleus basalis magnocellularis of rats: selective impairment of working memory in the double Y-maze. Brain Res 1992; 597: 66-73.

Beninger RJ, Kuhnemann S, Ingles JL, Jhamandas $\mathrm{K}$, Boegman RJ. Mnemonic deficits in the double Y-maze are related to the effects of nucleus basalis injections of ibotenic and quisqualic acid on choline acetyltransferase in the rat amygdala. Brain Res Bull 1994; 35: 147152.

Bermudez-Rattoni F, Rusiniak KW, Garcia J. Flavor-illness aversions: potentiation of odor by taste is disrupted by application of novocaine into amygdala. Behav Neural Biol 1983; 37: 61-75.

Bermudez-Rattoni F, Grijalva CV, Kiefer SW, Garcia J. Flavor-illness aversions: the role of the amygdala in the acquisition of taste-potentiated odor aversions. Physiol Behav 1986; 38: 503508.

Biggan SL, Beninger RJ, Cockhill J, Jhamandas K, Boegman RJ. Quisqualate lesions of rat NBM: selective effects on working memory in a double Y-maze. Brain Res Bull 1991; 26: 613-616.

Bormann J. Electrophysiology of $\mathrm{GABA}_{\mathrm{A}}$ and $\mathrm{GABA}_{B}$ receptors subtypes. Trends Neurosci 1988; 11: 112-116.

Bowery NG, Hudson AL, Price GW. GABA And
$\mathrm{GABA}_{\mathrm{B}}$ receptor site distribution in rat central nervous system. Neurosci 1987; 20: 365-383.

Bouton ME, Kenney FA, Rosengard C. Statedependent fear extinction with two benzodiazepine tranquilizers. Behav Neurosci 1990; 104: 44-55.

Brailowsky S, Kunimoto M, Menini C, Silva-Barrat C, Riche D, Naquet R. The GABA-withdrawal syndrome: a new model of focal epileptogenesis. Brain Res 1988; 442: 175-179

Brailowsky S, Menini C, Silva-Barrat C, Naquet R. Epileptogenic gamma-aminobutyric-acid withdrawal syndrome after chronic, intracortical infusion into baboons. Neurosci Lett 1987; 74: 75-80.

Brailowsky S, Silva-Barrat C, Menini C, Riche D, Naquet R. Effects of localized, chronic GABA infusions into different cortical areas of the photosensitive baboon, Papio papio. Electroencephalogr Clin Neurophysiol 1989;72: 147-156.

Browne SE, Muir JL, Robbins TW, Page KJ, Everitt BJ, McCulloch J. The cerebral metabolic effects of manipulating glutamatergic systems within the basal forebrain in conscious rats. Eur J Neurosci 1998; 10: 649-663.

Bures, J. Neurobiology of memory: the significance of anomalous findings. In: McGaugh JL, Weinberger NM, Lynch G, eds., Brain Organization and Memory: Cells, Systems, and Circuits. New York: Oxford University Press, 1990: 3-19.

Bures J, Buresova O. Reversible lesions allow reinterpretation of system level studies of brain mechanisms of behavior. Concepts Neurosci 1990; 1: 69-89.

Casamenti F, DiPatre PL, Bartolini L, Pepeu G. Unilateral and bilateral nucleus basalis lesions: differences in neurochemical and behavioral recovery. Neurosci 1988; 24: 209-215.

Chu DCM, Albin RL, Young AB, Penney JB. Distribution and kinetics of $\mathrm{GABA}_{B}$ binding sites in rat central nervous system: a quantitative autoradiographic study. Neurosci 1990; 34: 341-357.

Colpaert FC. Amnesic trace locked into the benzodiazepine state of memory. Psychopharmacology 1990; 102: 28-36.

DeSousa NJ, Beninger RJ, Jhamandas K, Boegman RJ. Stimulation of GABAB receptors in the basal forebrain selectively impairs working memory of rats in the double Y-maze. Brain Res 1994; 641: 29-38.

Di Scala G, Schmitt $P$ and Karli P. Unilateral injection of GABA agonists in the superior colliculus: asymetry to tactile stimulation. Pharmacol Biochem Behav 1983; 19: 284-285.

Di Scala G, Meneses S, Brailowsky S. Chronic 
infusions of GABA into the medial frontal cortex of the rat induce a reversible delayed spatial alternation deficit. Behav Brain Res 1990; $40: 81-84$.

Dudchenko P, Sarter M. GABAergic control of basal forebrain cholinergic neurons and memory. Behav Brain Res 1991; 42: 33-41.

Dunnett SB, Everitt BJ, Robbins TW. The basal forebrain-cortical cholinergic system: interpreting the functional consequences of excitotoxic lesions. Trends Neurosci 1991; 14: 494-501

Dunnett SB, Whishaw IQ, Jones GH, Bunch ST. Behavioural, biochemical and histochemical effects of different neurotoxic amino acids injected into nucleus basalis magnocellularis of rats. Neuroscience 1987; 20: 653-669.

Ellman GL, Courtney KD, Andres VJr, Featherstone RM. A new and rapid colorimetric determination of acetylcholinesterase activity. Biochem Pharmacol 1961; 7: 88-95.

Everitt HJ, Robbins TW, Evenden JL, Marston HM, Jones GH, Sirkiă TE. The effects of excitotoxic lesions of the substantia innominata, ventral and dorsal globus pallidus on the acquisition and retention of a conditional visual discrimination: implications for cholinergic hypothesis of learning and memory. Neurosci 1987; 22: 441-469.

Farah MJ. Neuropsychological inference with an interactive brain: a critique of the "locality" assumption. Behav Brain Sci 1994; 17 : 43-104.

Ferry B, Sandner G, Di Scala G. Neuroanatomical and functional specificity of the basolateral amygdaloid nucleus in taste-potentiated odor aversion. Neurobiol Learn Mem 1995; 64: 169-180.

Fonnum F. A rapid radiochemical method for the determination of choline acetyltransferase. J Neurochem 1975; 24: 407-409.

Fukuda H, Brailowsky S, Menini C, Silva-Barrat C, Riche D, Naquet R. Anticonvulsant effect of intracortical, chronic infusion of GABA in kindled rats: focal seizures upon withdrawal. Exp Neurol 1987; 98: 120-129.

Gallese V, Murata A, Kaseda M, Niki N, Sakata H. Deficit of hand preshaping after muscimol injection in monkey parietal cortex. Neuroreport 1994; 5: 1525-1529.

Gallo M, Roldan G, Bures J. Differential involvement of gustatory insular cortex and amygdala in the acquisition and retrieval of conditioned taste aversion in rats. Behav Brain Res 1992; 52: 91-97.

Gardiner IM, De Belleroche J, Premi BK, Hamilton MH. Effects of lesion of the nucleus basalis of rat on acetylcholine release in cerebral cortex: time course of compensatory events. Brain Res 1987; 407: 263-271.

Guzowski JF, McGaugh JL. Antisense oligodeoxynucleotide-mediated disruption of hippocampal cAMP response element binding protein levels impairs consolidation of memory for water maze training. Proc Natl Acad Sci USA 1997; 94: 2693-2698.

Hankins WG, Garcia J, Rusiniak KW. Dissociation of odor and taste in bait shyness. Behav Biol 1973; 8: 407-419.

Hardiman MJ, Ramnani N, Yeo CH. Reversible inactivations of the cerebellum with muscimol prevent the acquisition and extinction of conditioned nictitating membrane responses in the rabbit. Exp Brain Res 1996;1 10:235-247.

Hatfield T, Graham PW, Gallagher M. Tastepotentiated odor aversion learning: role of the amygdaloid basolateral complex and central nucleus. Behav Neurosci 1992; 106: 286-293.

Hernandez TD, Schallert T. Long-term impairment of behavioral recovery from cortical damage can be produced by short-term GABA-agonist infusion into adjacent cortex. Restor Neurol Neurosci 1990; 1: 323-330.

Hupé JM, Chouvet G, Bullier J. Spatial and temporal parameters of cortical inactivation by GABA. J Neurosci Meth 1999; 86: 129-143.

Ingham CA, Bolam JP, Smith AD. GABAimmuno-reactive synaptic boutons in the rat basal forebrain: comparison of neurons that project to the neocortex with pallidosubthalamic neurons. J Comp Neurol 1988; 273: 263-282

Iversen LL, Kelly JC. Uptake and metabolism of $\gamma$-aminobutyric acid by neurons and glial cells. Biochem Pharmacol 1975; 24: 933-938.

Jaffard R, Meunier M. Role of the hippocampal formation in learning and memory. Hippocampus 1993; 3: 203-217.

Jarrard LE. On the role of the hippocampus in learning and memory in the rat. Behav Neural Biol 1993; 60: 9-26.

Jerusalinsky D, Quillfeldt JA, Walz R, Da Silva RC, Bueno e Silva M, Bianchin M, et al. Effect of the infusion of the GABA-A receptor agonist, muscimol, on the role of the entorhinal cortex, amygdala, and hippocampus in memory processes. Behav Neural Biol 1994; 61: 132-138.

Kolb B. Functions of the frontal cortex of the rat: a comparative review. Brain Res 1984; 320: 65-98.

Krogsgaard-Larsen P. GABA synaptic mechanisms: stereochemical and conformational requirements. 
Med Res Rev 1988; 8: 27-56.

Krupa DJ, Weng J, Thompson RF. Inactivation of brainstem motor nuclei blocks expression but not acquisition of the rabbit's classically conditioned eyeblink response. Behav Neurosci 110: 219-227.

Kuhar MJ. A GABA transporter cDNA has been cloned. Trends Neurosci 1990; 13: 473-474.

Lamprecht R, Hazvi S, Dudai Y. cAMP response element-binding protein in the amygdala is required for long- but not short-term conditioned taste aversion memory. J Neurosci 1997; 17: 8443-8450.

Lomber SG. The advantages and limitations of permanent or reversible deactivation techniques in the assessment of neural function. J Neurosci Meth 1999; 86: 109-117.

Lynch G. Memory and the brain: unexpected chemistries and a new pharmacology. Neurobiol Learn Mem 1998; 70 : 82-100.

Ma YL, Wang HL, Wu HC, Wei CL, Lee EH. Brain-derived neurotrophic factor antisense oligonucleotide impairs memory retention and inhibits long-term potentiation in rats. Neuroscience 1998; 82: 957-967.

McDonald MP, Overmier JB. Present imperfect: a critical review of animal models of the mnemonic impairments in Alzheimer's disease. Neurosci Biobehav Rev 1998; 22: 99-120.

Majchrzak M, Brailowsky S, Will B. Chronic infusion of GABA and saline into the nucleus basalis magnocellularis of rats: II. Cognitive impairments. Behav Brain Res 1990; 37: 45-56.

Majchrzak M. L'infusion chronique intracérébrale de GABA comme modèle d'étude du rôle du noyau basal magnocellulaire dans l'expression des fonctions cognitives et sensorimotrices chez le Rat. Thèse de l'Université Louis Pasteur (spécialité Neurosciences), Strasbourg, France, 1992; 1-259.

Majchrzak M, Brailowsky S, Will B. Chronic infusion of GABA into the nucleus basalis magnocellularis or frontal cortex of rats: a behavioral and histological study. Exp Brain Res 1992a; 88: 531-540.

Majchrzak M, Nehlig A, Will B. Local cerebral glucose utilization during chronic infusion of GABA into the nucleus basalis magnocellularis of rats. Exp Neurol 1992b; 116: 256-263.

Malpeli JD. Reversible inactivation of subcortical sites by drug injection. J Neurosci Methods 1999; 86: 119-128.

Martin JH. Autoradiographic estimation of the extent of reversible inactivation produced by micro-injection of lidocaine and muscimol in the rat. Neurosci Lett 1991; 127: 160-164.

Martin JH, Ghez C. Differential impairments in reaching and grasping produced by local inactivation within the forelimb representation of the motor cortex in the cat. Exp Brain Res 1993; 94: 429-443.

Martin JH, Ghez C. Pharmacological inactivation in the analysis of the central control of movement. J Neurosci Meth 1999; 86:145-159.

Mason CR, Miller LE, Baker JF, Houk JC. Organization of reaching and grasping movements in the primate cerebellar nuclei as revealed by focal muscimol inactivations. J Neurophysiol 1998; 79: 537-554.

Matsumura M, Sawaguchi T, Oishi T, Ueki K, Kubota K. Behavioral deficits induced by local injection of bicuculline and muscimol into the primate motor and premotor cortex. J Neurophysiol 1991; 65: 1542-53.

Meneses S, Galicia O, Brailowsky S. Chronic infusions of GABA into the medial prefrontal cortex induce spatial alternation deficits in aged rats. Behav Brain Res 1993; 57: 1-7.

Milak MS, Shimansky Y, Bracha V, Bloedel JR. Effects of inactivating individual cerebellar nuclei on the performance and retention of an operantly conditioned forelimb movement. J Neurophysiol 1997; 78: 939-959.

Mugnaini E, Oertel WH. An atlas of the distribution of GABAergic neurons and terminals in the rat CNS as revealed by GAD immunohistochemistry. In: Björklund A and Hökfelt T. eds. Handbook of Chemical Neuroanatomy, Vol 4: GABA and Neuropeptides in the CNS, Part I. Amsterdam: Elsevier, 1985; 436-608.

Muir JL, Robbins TW, Everitt BJ. Disruptive effects of muscimol infused into the basal forebrain on conditional discrimination and visual attention: differential interactions with cholinergic mechanisms. Psychopharmacology 1992; 107: 541-550.

Muir JL, Page KJ, Sirinathsinghji DJ, Robbins TW, Everitt BJ. Excitotoxic lesions of basal forebrain cholinergic neurons: effects on learning, memory and attention. Behav Brain Res 1993, 57: 123-131.

Muir JL, Everitt BJ, Robbins TW. Reversal of visual attentional dysfunction following lesions of the cholinergic basal forebrain by physostigmine and nicotine but not by the 5-HT3 receptor antagonist, ondanetron. Psychopharmacology 1995; 118: 82.

Muller J, Corodimas KP, Fridel Z, LeDoux JE. 
Functional inactivation of the lateral and basal nuclei of the amygdala by muscimol infusion prevents fear conditioning to an explicit conditioned stimulus and to contextual stimuli. Behav Neurosci 1997; 111: 683-691.

Oberling P, Di Scala G, Sandner G. Ketamine acts as an internal contextual stimulus that facilitates the retrieval of weak associations in conditioned taste aversion. Psychobiol 1996; 24: 300-305.

Pang K, Williams MJ, Egeth H, Olton DS. Nucleus basalis magnocellularis and attention: effects of muscimol infusions. Behav Neurosci 1993; 107: 1031-1038.

Ramnani N, Yeo CH. Reversible inactivations of the cerebellum prevent the extinction of conditioned nictitating membrane responses in rabbits. J Physiol (Lond) 1996; 495: 159-168.

Robbins TW, Everitt BJ, Marston HM, Wilkinson J, Jones GH, Page KJ, Comparative effects of ibotenic acid and quisqualic acid-induced lesions of the substantia innominata on attentional function in the rat: Further implications for the role of the cholinergic neurons of the nucleus basalis in cognitive processes. Behav Brain Res 1989; 35: 221-240.

Sinnamon HM, Benaur M. GABA injected into the anterior dorsal tegmentum (ADT) of the midbrain blocks stepping initiated by stimulation of the hypothalamus. Brain Res 1997; 766: 271-275.

Torres EM, Perry TA, Blockland A, Wilkinson LS, Wiley RG, Lappi DA, Dunnet SB. Behavioural, histohemical and biochemical consequences of selective immunolesions in discrete regions of the basal forebrain cholinergic system. Neurosci 1994; 63: 95-122.

Tulving E. Concepts of human memory. In: Squire LR, Weinberger NM, Lynch G, McGaugh JL, eds, Memory: Organization and Locus of Change. Oxford University Press, 1991; 3-32.

Wenk GL, Olton DS. Recovery of neocortical acetyltransferase activity following ibotenic acid injection into the nucleus basalis of Meynert in rats. Brain Res 1984; 293: 184-186.

Wenk GL, Stoehr JD, Quintana G, Mobley S, Wiley RG. Behavioral, biochemical, histological, and electrophysiological effects of 192 IgG-saporin injections into the basal forebrain of rats. J Neurosci 1994; 14: 5986-5995.

Will BE, Toniolo G, Brailowsky TD. Unilateral infusion of GABA and saline into the nucleus basalis of rats: 1. Effects on motor function and brain morphology. Behav Brain Res 1988; 27: 123-129.

Willner P, Bianchin M, Walz R, Bueno e Silva M, Zanatta MS, Izquierdo I. Muscimol infused into the entorhinal cortex prior to training blocks the involvement of this area in post-training memory processing. Behav Pharmacol 1993; 4: 95-99.

Wood PL, Richard J. GABAergic regulation of the substantia innominata-cortical cholinergic pathway. Neuropharmacol 1982; 21: 969-972.

Zaborsky L; Heimer L, Eckenstein F, Leranth C. GABAergic input to cholinergic forebrain neurons: An ultrastructural study using retrograde tracing of HRP and double immunolabeling. J Comp Neurol 1986; 250: 282-295. 

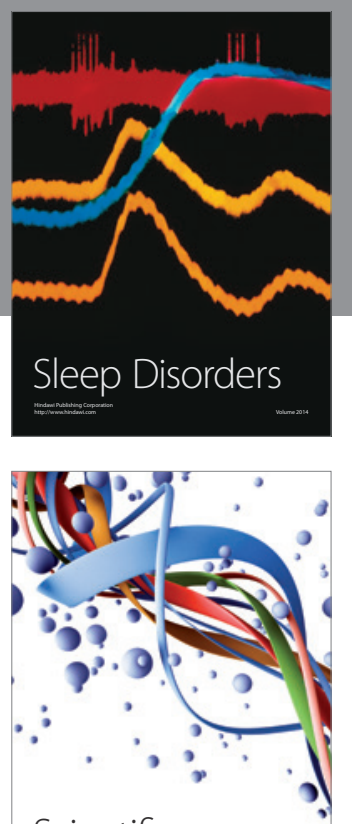

Scientifica
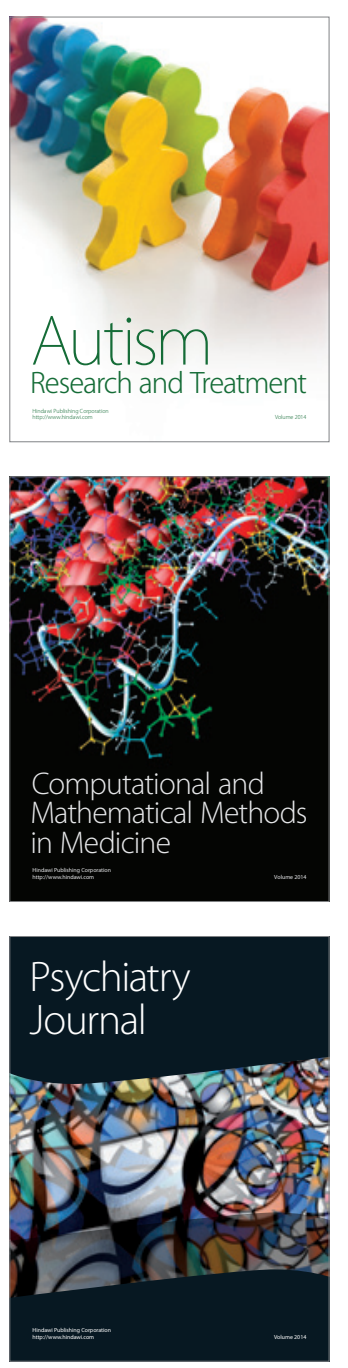
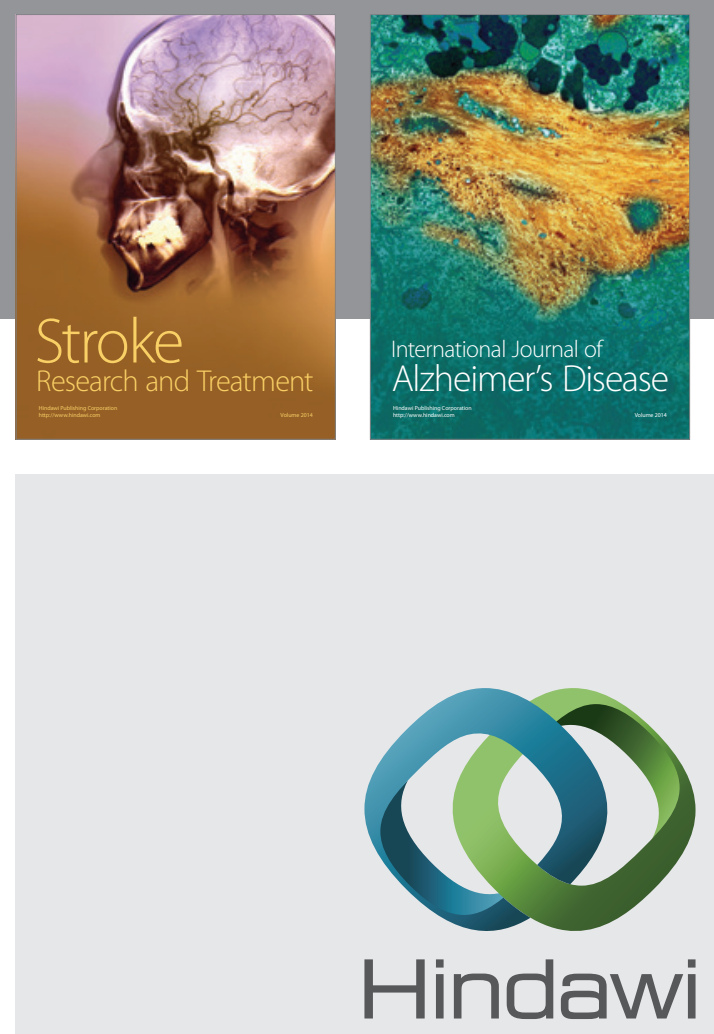

Submit your manuscripts at

http://www.hindawi.com
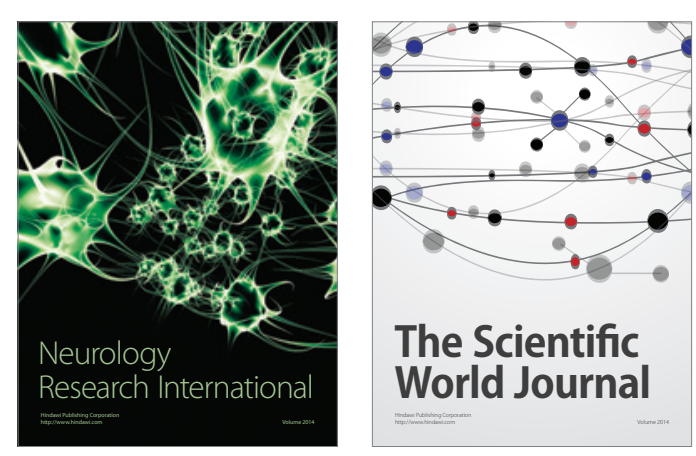

The Scientific World Journal

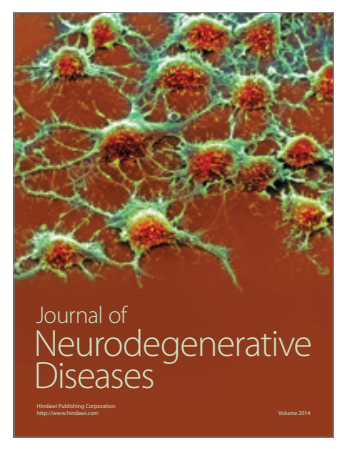

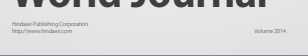

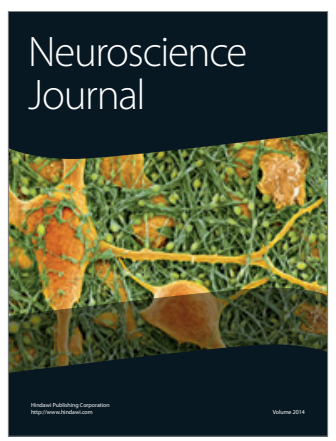

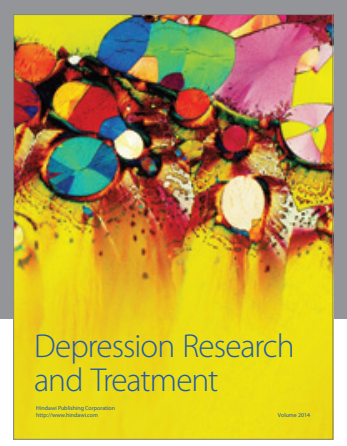
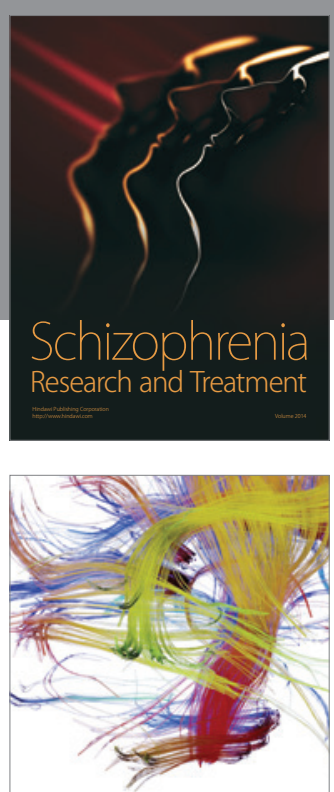

Brain Science

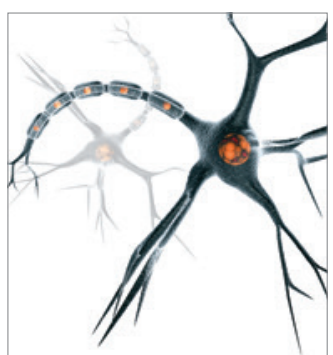

Neural Plasticity
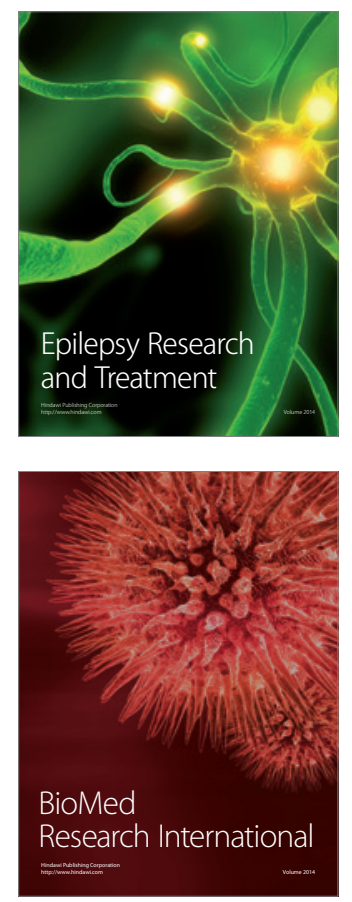

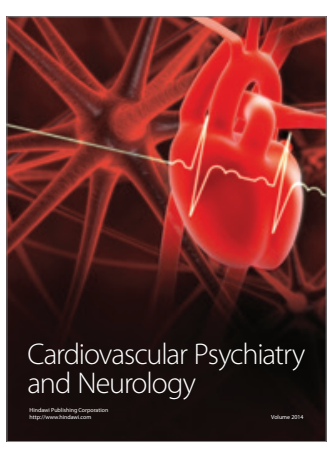

Parkinson's

Disease
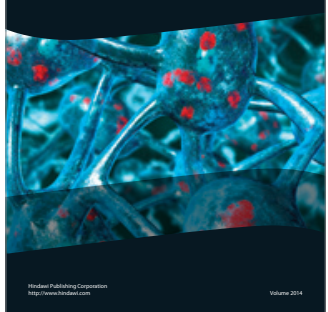